Authors: Krzysztof Tubielewicz, Ireneusz Piotr Chmielik, Hubert Michalczuk

Title of article: „Modelowanie powstawania naprężeń w warstwie wierzchniej” (“Modeling of stressing in a surface layer”)

Mechanik, Vol. 91, No. 7 (2018): pages 479-481

DOI: https://doi.org/10.17814/mechanik.2018.7.60

\title{
Modeling of stressing in a surface layer
}

\section{Modelowanie powstawania naprężeń w warstwie wierzchniej}

\section{KRZYSZTOF TUBIELEWICZ IRENEUSZ PIOTR CHMIELIK HUBERT MICHALCZUK *}

The computer simulation of the state of stress occurring in the contact zone during the influence of mechanical and caulking deformations caused by the process of burnishing was presented. The simulation results were based on the I-DEAS Master Series from SDRC from Milford. KEYWORDS: burnishing technology, stress, finite element method FEM

In the processes of forming the surface layer of machine elements there are complex physicochemical phenomena causing the formation of internal stresses. Their cause is so-called external deformations - caused mainly by external forces and thermal phenomena - disturbing the existing state of equilibrium of the energy structure of the material, which leads to the formation of internal forces, manifesting as stress and deformation. The description of these processes is extremely complex, however, for the purposes of technology, it is possible to determine qualitative models of the formation of internal stresses in the surface layer. Therefore, using the basic concepts of form and volume deformation, it stands out:

- model of plastic deformations,

- volumetric - structural deformation model.

In addition, in the model of deformation - plastic mechanical (cold) and warm [1] models can be distinguished. If the external interaction is associated with mechanical forces, which are usually forces occurring in the process of shaping the product, then after the theoretical elimination of heat, a "force - strains - internal stresses" scheme is obtained, i.e. a model of mechanical plastic deformation. This model is appropriate for technologies where thermal influences can be limited, e.g. in cold plastic working processes and most burnishing technologies [2]. If, however, in external interactions, the exclusive influence of heat associated with the occurrence of elevated temperature is assumed, which results in deformations that give rise to internal stresses, then the thermal model of plastic deformation is applicable. It is suitable for shaping steel products at temperatures below A1. The model of thermal plastic deformation can be used, for example, in the analysis of processes: hot plastic forming, spark erosion machining and (partly) electromechanical cutting treatment [3]. However, in practice almost always there are indirectly mixed models in which the simultaneous interaction of forces and heat results in the formation and different orientation of the own stresses in the surface layer.

When analyzing the formation of internal stresses in the surface layer during some burnishing processes - dynamic or electromechanical - the influence of heat, causing rapid and uneven heating of the deformation area, can not be neglected.

The non-stationary temperature distribution in the deformation zone causes uneven changes in the volume of the micro-granules of the material and, as a consequence, the occurrence of thermal stresses. The layers of material lying outside the deformation zone counteract the expansion of the heated layers, resulting in thermal compressive or tensile stresses.

Thermal stresses sum up with stresses resulting from plastic deformations and the stress mark is reoriented in the top layer. Depending on the size of the gradient of thermal stresses and stresses resulting from plastic deformation, the maximum values of residual stresses may remain on the surface or "descend" inside the top layer (fig. 1).

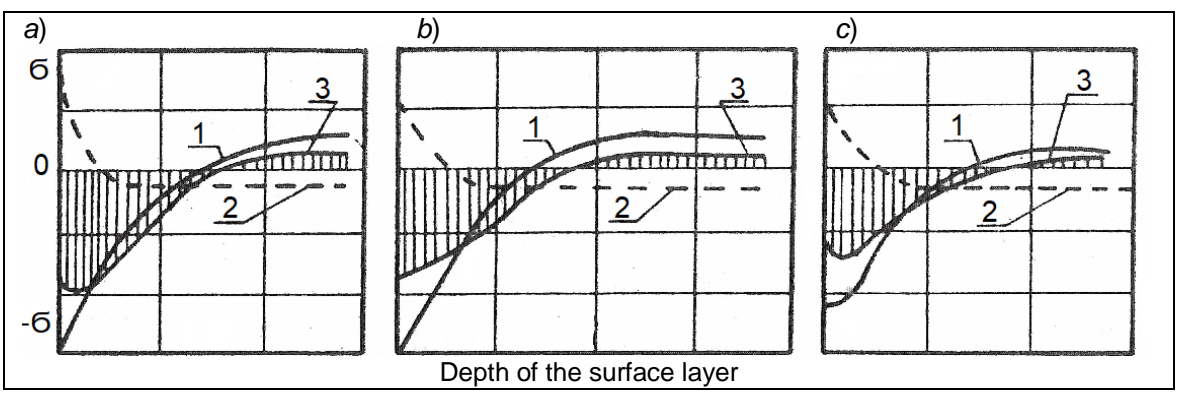

Fig. 1. Scheme of stress formation in the surface layer after burnishing: with maximum stresses at a given depth $(a, c)$, with maximum stresses on the surface $(b)$. Markings: 1 - stresses caused by plastic deformation, 2 - thermal stresses, 3 - result stresses

\footnotetext{
* Prof. dr hab. inż. Krzysztof Tubielewicz (krzysztoftubielewicz@op.pl) - emerytowany prof. zw. Politechniki Częstochowskiej; dr inż. Ireneusz Piotr Chmielik (p.chmielik@taylor-hobson.pl) - Taylor Hobson Polska; mgr inż. Hubert Michalczuk (hubertmichalczuk@poczta.onet.pl) - Politechnika Częstochowska, Instytut Technologii Mechanicznych; P.P.U. MAG-RYŚ Rędziny - Nowoczesna Narzędziownia
} 
At the maximum stresses within the surface layer, the thermal effect in each case will reduce the magnitude of ultimate stresses, but their maximum almost always remains at a certain distance from the surface of the object. In some processes of burnishing treatment (in electromechanica burnishing) the mechanism of forming own stresses should be considered taking into account the mutual influence of plastic deformations and thermal processes taking place in the surface layer.

\section{Computer simulations of the state of stress}

In order to analyze the stress distribution for electromechanical burnishing, computer (numerical) simulation of the stress state was carried out, when in the contact zone there is a temperature corresponding to the structural change temperature for the stable heat propagation state, and the contact field corresponds to the plasticity conditions for the data parameters $\left(I, U, F_{\mathrm{v}}, T\right)$.

The simulation was performed in the I-DEAS Master Series 7 and 8 program by SDRC from Milford, Ohio. On the surface of the object in the form of a cylinder an area of $5 \times 5 \mathrm{~mm}$ and a depth of $4 \mathrm{~mm}$ and a radius of $R=20 \mathrm{~mm}$ were isolated (fig. 2) - the shape of the tool contact zone $(\mathrm{N})$ with the object $(\mathrm{P})$ was modeled as an ellipse, to which the pressing force $F=150 \div 350 \mathrm{~N}$ was applied at a temperature of $293 \div 1110 \mathrm{~K}$. The research involved the use of tetrahedral finite elements described in the Cartesian coordinate system $x, y, z$. A surface mesh of $0.1 \mathrm{~mm}$ was applied to this area. A $0.3 \mathrm{~mm}$ solid mesh was then used, resulting in automatic compacting of the split (fig. 2). Selected simulation results are shown in figs. 3-5.

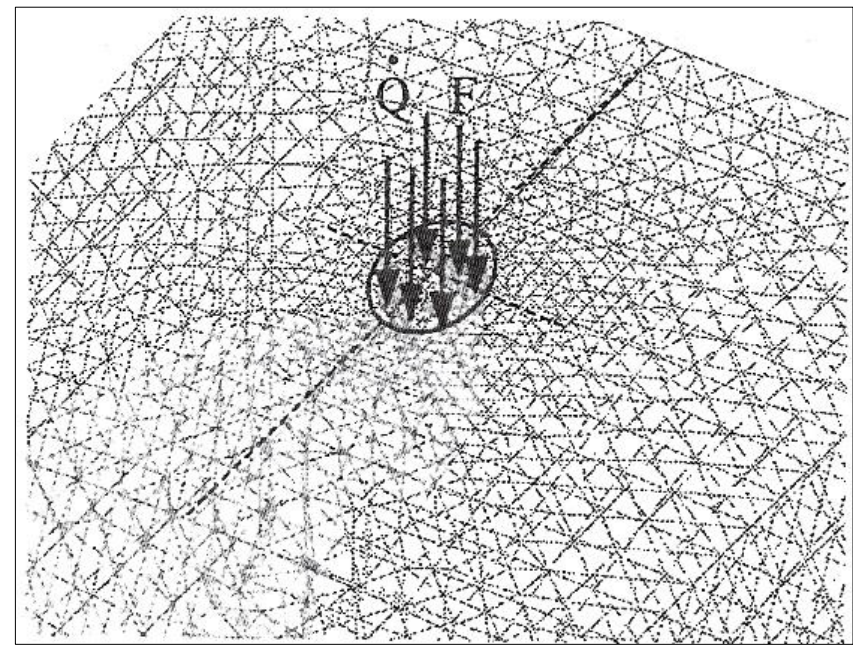

Fig. 2. Strength and temperature model with finite element mesh

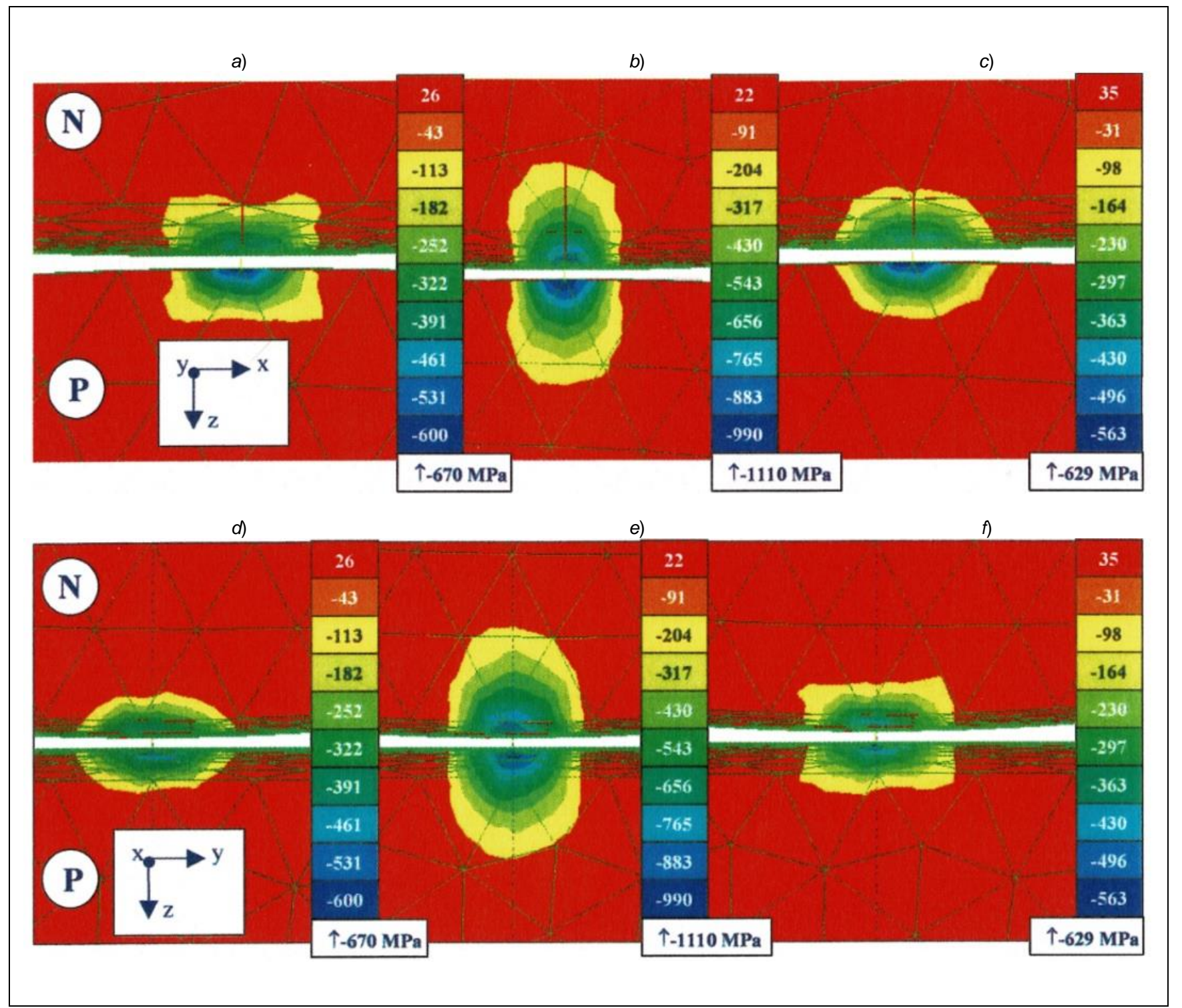

Fig. 3. Distribution of stresses $\sigma_{\mathrm{x}}, \sigma_{\mathrm{z}}, \sigma_{\mathrm{Y}}$ (at force $F=150 \mathrm{~N}$ and at temperature $T=293 \mathrm{~K}$ ) in the contact zone: $a-c$ ) stresses in the plane $\left.x_{0 z} ; d-f\right)$ stresses in the plane $y_{0 z}$ 


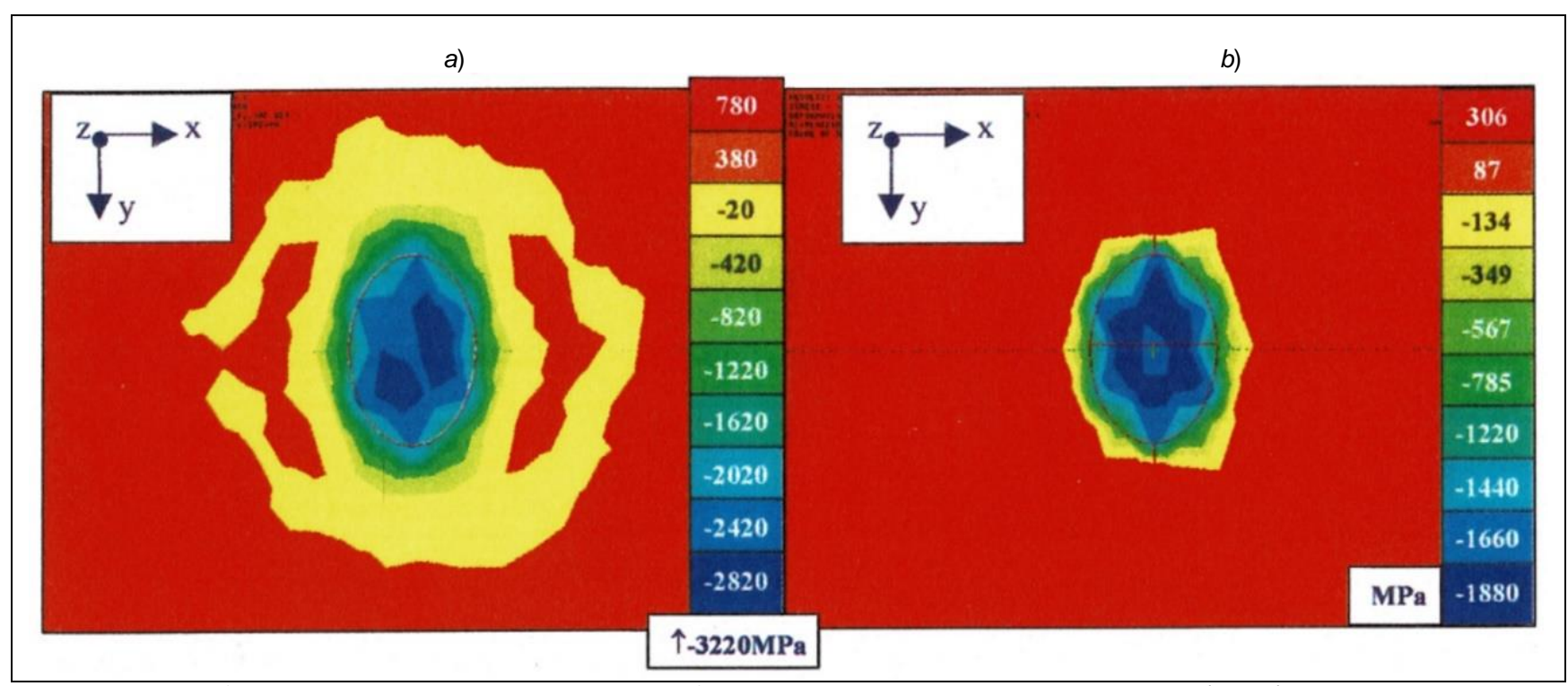

Fig. 4. Distribution of stresses in the contact zone at the pressure force $F=350 \mathrm{~N}$ and at temperature $\left.T=1120 \mathrm{~K}: a) \sigma_{\mathrm{Y}}, b\right) \sigma_{\mathrm{Z}}$

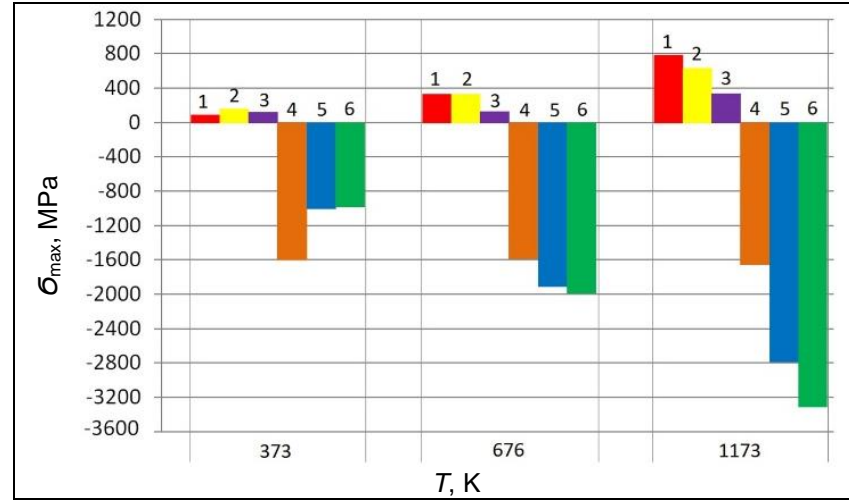

Fig. 5. Stress values obtained from computer simulation (FEM) for different temperature of contact zone at force $F=350 \mathrm{~N}\left(1,6-\sigma_{\mathrm{Y}}\right.$; $\left.2,5-\sigma_{x} ; 3,4-\sigma_{z}\right)$

The results of the simulation indicate a significant increase in the compressive stress in the area below the surface of the contact area (fig. 5): in the direction according to the tool feed, $\sigma_{\mathrm{Z}} \approx-1800 \mathrm{MPa}$ was obtained, and in the direction consistent with the pressure force, i.e. perpendicular to the surface burnished $-\sigma_{\mathrm{z}} \approx-1600 \mathrm{MPa}$.

\section{Final remarks}

The results of numerical simulations (figs. 3-5) allowed for a detailed analysis of stress distribution in a spatial layout. In areas in the deformation zone (fig. 4b), the tensile stresses reached values: $\sigma_{Y} \approx 780 \mathrm{MPa}-$ in the direction of the tool feed direction, $\sigma_{Z} \approx 300 \mathrm{MPa}$ - in the direction of the feed direction. In addition, it can be noticed that the state of stresses induced by thermal-mechanical phenomena occurring during burnishing depends in this method mainly on the temperature (fig. 5) in the contact zone.

As is known, the properties of the surface layer of the manufactured elements depend to a large extent on the state of internal stresses [2, 4, 5]. The model of their formation in this method of processing is complex and determined by many factors, mainly the size of the crush and the temperature that causes phase transitions.

A significant increase in temperature into the material results in a sudden increase in compressive stresses in the top layer, which is compounded by the pressure of the raking tool, to a value equal to the plasticity limit at a given temperature. Heated (to the temperature above AC3 permanently sub-eutectoidal) material of the surface layer at the moment of cooling initially begins to shrink (to achieve the transformation temperature austenite-martensite), and then increases its volume about $1 \div 3 \%$ (transformation $y \rightarrow \alpha$ ), so more so than under the influence of the temperature gradient. The martensitic transformation occurs most intensively in the subsurface layer, which increases its volume. Zones located deeper cool down more slowly, and the structural changes take place with a certain delay, stretching the material located below the subsurface layer, which causes additional compression of the material located directly under the contact surface. The resulting tensile and compressive stresses add up, resulting in a specific state of result stresses, which depends on the type of material and parameters of electromechanical burnishing.

The results of the simulation indicate the possibility of obtaining in the surface layer electro-mechanical burn both compressive and tensile stresses, at different depths and with different distribution and different location of peaks [6].

\section{REFERENCES}

1. Tubielewicz K. „Analiza naprężeń powstałych w warstwie wierzchniej podczas procesu nagniatania". Częstochowa: Wydawnictwo Politechniki Częstochowskiej, 1993.

2. Tubielewicz K. „Analiza zjawisk towarzyszacych odkształceniu warstwy wierzchniej w procesie nagniatania”. Seria Monografie 13. Częstochowa: Wydawnictwo Politechniki Częstochowskiej, 1990.

3. Musialik J. „Zjawiska termomechaniczne determinujące właściwości warstwy wierzchniej stali nagniatanej elektromechanicznie". Seria Monografie 93. Częstochowa: Wydawnictwo Politechniki Częstochowskiej, 2003.

4. Tubielewicz K., Musialik J. „Der Zustand der Stahldeckschicht nach dem elektromechanischen Glattwalzen". Tribologie und Schmirungstechnik. 47, 3 (2000): pp. 47-49.

5. Musialik J., Tubielewicz K. „Warstwa wierzchnia stali po nagniataniu elektromechanicznym”. IV Międzynarodowa Konferencja „Wpływ technologii na stan warstwy wierzchniej WW 99", Lubniewice-Gorzów Wielkopolski 1999, pp. 211-219.

6. Tubielewicz K., Musialik J. „Мікроструктурні зміни у сталях під час поверхневої пластичної деформації електромеханічним методом". Physicochemical Mechanics of Materials. 35, 5 (1999): pp. 102-104.

Translation of scientific articles, their computer composition and publishing them on the website www.mechanik.media.pl by original articles in Polish is a task financed from the funds of the Ministry of Science and Higher Education designated for dissemination of science.

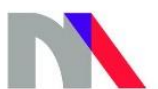

